\title{
Unraveling pre-Columbian occupation patterns in the tropical forests of French Guiana using an anthracological approach
}

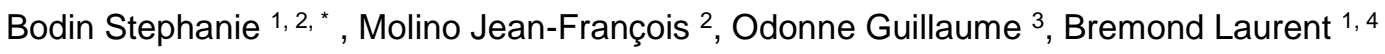

${ }^{1}$ ISEM, Université Montpellier, CNRS, EPHE, IRD, UMR 5554, C/C 065, Place Eugène Bataillon, 34095, Montpellier Cedex 05, France

2 AMAP, IRD, CIRAD, CNRS, INRA, Université Montpellier, UMR AMAP, TA A51/PS2, 34398,

Montpellier Cedex 05, France

${ }^{3}$ LEEISA (Laboratoire Ecologie, Evolution, Interactions Des Systèmes Amazoniens), CNRS, Université

de Guyane, Centre de Recherche Montabo, IFREMER, 275 Route de Montabo, BP 70620, 97300,

Cayenne, French Guiana

4 École Pratique Des Hautes Études, PSL Research University, Les Patios Saint-Jacques 4-14 rue

Ferrus, 75014, Paris, France

* Corresponding author : Stephanie Bodin, email address : stephanie.bodin@umontpellier.fr

\begin{abstract}
:
In Amazonia, a growing body of studies has shown that rainforests were affected by human occupation in many areas during pre-Columbian times, inducing changes in their floristic compositions. The northern part of Amazonia, and in particular the Guiana Shield, is much less studied, although past human occupations have also been documented in this region. Therefore, the actual impact of pre-Columbian societies on Guianan forests is still poorly known. Here we explore 12 sites in the dense forest of Nouragues, central French Guiana, ranging from a priori non-anthropogenic to clearly anthropogenic, using an anthracological approach. Soil charcoals were radiocarbon dated to assess the chronology of the past human occupations, and identified to determine shifts in vegetation cover. Our results show that two main periods of occupation can be distinguished on several sites in the Nouragues area: a first one between ca. 1,300 and 1,000 cal bp and a second one between ca. 600 and $400 \mathrm{cal} \mathrm{bp}$. Charcoal identification reveals the presence of a secondary vegetation during this most recent period of occupation, as shown by the presence of pioneer and heliophilic taxa, suggesting that human activities induced and favored this kind of vegetation. The presence of valuable wood and edible species in the anthracological record could reflect selective exploitation of the former around dwelling areas and a concentration of the latter within anthropogenic sites. As shown by our anthracological results, all the sites which contained charcoal were once under forest cover, including those that are now covered by pseudo-bamboos or by liana forests. We therefore suggest that the type of human activity (e.g. dwelling or food production) may have had different impacts on the structure and composition of subsequent vegetation resulting either in anthropogenic forests or liana and pseudo-bamboo patches after land abandonment.
\end{abstract}


Keywords : Charcoal, Anthracology, Lasiacisthicket, Liana forest, Amazonia, Pre-Columbian occupation, Historical ecology 


\section{Introduction}

The Amazonian rainforest has long been described as pristine, but a growing body of studies supports the hypothesis that, in many places, it has been strongly influenced by pre-Columbian land management (e.g. Posey 1985; Denevan 1992; Balée 1993, 2013; Heckenberger et al. 2003, 2007; Levis et al. 2012, 2017; Clement et al. 2015; Odonne et al. 2019). Nevertheless, the findings of some investigators suggest that such an impact cannot be extrapolated to the whole Amazon basin (Barlow et al. 2012; McMichael et al. 2012; Piperno et al. 2015, 2019). While the debate persists on the extent to which the Amazonian forest has been modified by pre-Columbian societies, there are many clues to their presence, land use and resource management throughout this vast region. The most obvious are archaeological artifacts, such as geoglyphs and earthworks (Rostain 2008; Heckenberger and Neves 2009; de Souza et al. 2018), but also the abundance of useful keystone species in the present-day landscape (Balée 1994; Erickson and Balée 2006; Clement et al. 2010, 2015; Levis et al. 2017) and in the archaeobotanical archives (e.g. Piperno and Pearsall 1998; Oliver 2008). Anthropogenic soils are also clear evidence. These brown to black soils, rich in charcoals and potsherds, found along riverine bluffs of the Amazon and its tributaries also attest to these ancient activities. Called Amazonian Dark Earths (ADE) or terra preta (Kern et al. 2003; Glaser and Birk 2012; McMichael et al. 2014), these soils contain large amounts of organic matter and associated nutrients that give them a much higher chemical fertility than tropical Ferralsols (Glaser and Birk 2012). ADE are associated with anthropogenic secondary forests, with a higher density of domesticated species (Woods and McCann 1999; German 2003; Junqueira et al. 2010), smaller mature trees (German 2001, 2003), a lower canopy and a more closed understory (Woods and McCann 1999) than those on nonanthropogenic soils.

While studies on pre-Columbian occupation have flourished in central and western Amazonia, the northern part, and particularly the Guiana Shield, is far 
less investigated, though also hosting vestiges of these ancient societies. The best known are the raised fields of the savannah coastal zone (Rostain 2008; Iriarte et al. 2010, 2012; McKey et al. 2010), which has been studied more by archaeologists than the dense forests of the hinterlands. However, archaeological surveys and excavations in the forest have revealed pre-Columbian sites, some of which are unique to the Guianas; these are peculiar ditched sites, whose ditch surrounds the top of a hill. They are mainly known in French Guiana where they are called "montagnes couronnées" (Abonnenc 1952); in this region, LiDAR imagery allowed the discovery of dozens of such sites in the dense forest (e.g. Sabatier et al. 2017). The function of these sites remains to be determined; they could correspond to defensive places (Rostain 1994 cited in Rostain 2008) or to ceremonial areas (Versteeg 2003). To date, only a few have been the subject of archaeological excavations (Mazière and Mazière 1994; Versteeg 2003; Mestre et al. 2013). In addition to these peculiar earthworks, there are also small patches of bamboos or liana forests within the forest (Gasc and Sastre 1978; Sabatier and Prévost 1989; de Granville 1990; Bongers et al. 2013). Some are associated with dark soils enriched with potsherds and charcoal, but it is not certain that all have an anthropogenic origin.

In this paper, we aim to determine how pre-Columbian occupations have influenced the present-day vegetation of the Nouragues Natural Reserve in French Guiana using an anthracological approach, which is quite new in this region. We address this issue with the following questions:

1. What is the chronology of human occupations?

2. Do burnt taxa correspond to a dense or open forest, with mature or pioneer forest species?

3. Is the presence of liana and pseudo-bamboo patches in the present-day landscape the consequence of previous human occupations?

To answer these questions, we collected, dated and identified charcoal assemblages from soils in twelve sites distributed under different vegetation covers, including pseudo-bamboo thickets and liana forests, each presenting different levels of past human disturbance, from apparently non-anthropized to clearly human impacted, as shown by the presence of earthworks, archaeological artifacts, soil analyses and the abundance of domesticated tree species. 


\section{Material and methods}

\section{Regional setting}

The study was undertaken in the Nouragues Natural Reserve, central French Guiana, near the two base camps 'Saut Pararé' $\left(4^{\circ} 02^{\prime} \mathrm{N}-52^{\circ} 41^{\prime} \mathrm{W}\right)$ and 'Inselberg' $\left(4^{\circ} 05^{\prime} \mathrm{N}-52^{\circ} 41^{\prime} \mathrm{W}\right)$ (Fig. 1). The Reserve has been free of long term human occupation since the early 18th century, when the Nouragues (or Norak) Amerindian populations, of the Tupí-Guaraní linguistic family, began to decline (Grenand 2006). Since then, only limited commercial activities were carried out in the first half of the 20th century, with gold panning and the exploitation of balata (Manilkara bidentata) and rosewood (Aniba rosaeodora). Hence, the Nouragues Reserve is an ideal place to study the impact of ancient human disturbances on the forest.

The climate is tropical humid (from "Af" to "Am" in Köppen-Geiger classification, Peel et al. 2007) with a mean annual rainfall of $2,990 \mathrm{~mm}$ and a mean annual temperature of $26.3^{\circ} \mathrm{C}$ (Grimaldi and Riéra 2001). The main dry season extends roughly from September to November and the little dry season usually occurs in March. The Reserve includes different types of vegetation: high and low forests, bamboo or pseudo-bamboo thickets dominated by Guadua sp. or Lasiacis ligulata, liana forest patches, swamp forests dominated by the palm Euterpe oleracea and rock savannas on the inselberg. The most dominant families are Burseraceae, Meliaceae, Sapotaceae, Lecythidaceae, Myristicaceae and Euphorbiaceae in the Saut Pararé area, and Fabaceae, Sapotaceae and Lecythidaceae in the Inselberg area (for a diameter at breast height $\geq 10 \mathrm{~cm}$, Poncy et al. 2001). Several studies have shown that edaphic factors, in particular the drainage conditions, but also the disturbance regime (Molino and Sabatier 2001), play a significant role in the floristic composition of the forests of French Guiana at local scales (Lescure and Boulet 1985; Sabatier et al. 1997; Pélissier et al. 2001). Nowadays, natural fires do not occur in the Nouragues reserve, even during storms, the climate being too moist (Tardy 1998). Nevertheless, natural fires did occur during the Holocene during dry events. Tardy (1998) highlighted 8 fire events in the Nouragues reserve coinciding with such abnormally dry events since ca. 13,000 BP; the last 4 (starting from 2,000 BP) being contemporaneous with human presence. 


\section{Study sites}

We investigated 12 sites, selected to reflect qualitatively and quantitatively different modalities of pre-Columbian occupations and distributed under different types of vegetation: high to low canopy forests with dense or sparse understory, hosting few or many edible palms, whose abundance in the landscape can be indicative of past land management (e.g. Balée 2013), pseudo-bamboo thickets dominated by Lasiacis, and liana forests. Each site presented different soil colors (from brown, yellow to red) and textures, with the soils of the Inselberg area being more clayey than those of the Saut Parare surroundings $(88.6 \pm 3.4 \%$ clay vs $61.4 \pm 12.5 \%$, respectively). The sites differed in the amounts of potsherds and charcoals, some of them lacking anthropogenic artifacts (sites 4 and 5). Two of them are earthworks detected by airborne LiDAR: a 'ring-ditched hill' (i.e. a hilltop surrounded by a ditch) and a circular ditched site located on a plateau (Fig. 2, Table 1).

Sites 1 to 8 are located in the Saut Parare area and sites 9 to 12 are in the Inselberg area (Fig. 1). Sites 1 and 2 are on the same hilltop, the first being in a Lasiacis ligulata thicket and the second 60 metres away under forest cover. On the ringditched hill, site 3 corresponds to the 'ditch' itself, which has presumably been filled with soil material from the hill top, forming a flattened surface, and site 8 corresponds to the hilltop. The ring-ditched hill is covered by a forest dominated by the edible palm Oenocarpus bataua. Site 4 is located on an alluvial terrace, in an apparently undisturbed forest. Site 5 is on a steep slope in a pseudo-bamboo thicket dominated by Lasiacis ligulata and Heliconia bihai. Sites 6 and 7 are situated on opposite sides of the same hill; the first is under a high canopy forest and the second is at the transition between a liana forest and a Lasiacis thicket. On the Inselberg side, sites 9 to 12 are located on the 'Grand Plateau', south-east of the basecamp. Site 9 corresponds to another ditched site, covered by a liana forest, and sites 10,11 and 12 are all situated under forest cover.

\section{Soil charcoal sampling}

We used different sampling methods for the recovery of soil charcoal during three fieldwork campaigns. The methods were adapted to fieldwork constraints and are synthesized in Table 2 . First, $80 \times 80 \mathrm{~cm}$ pits were dug in all sites for joint pedological, micromorphological and anthracological analyses. In sites 1 to 9, we 
collected $10 \mathrm{~L}$ of soil in each $10-\mathrm{cm}$ depth layer along the pit soil profile. We also collected charcoal fragments in the soil excavated during the digging process.

Second, in sites where charcoals were rather abundant in the pit, we sampled with a soil auger in a 1-ha area, centered on the pit, except for site 3 where we sampled at several points in the ditch. The objective was to cover a larger surface area to better approximate the taxonomic diversity at the stand scale. The sampling depth depended on the depth of the bedrock and on the type of soil: when the soil became red and charcoals were rare or absent, we did not go any further and the sampling was stopped. For lack of time, the pits at sites 10 to 12 were not sampled, and sites 11 and 12 were not sampled with the soil auger. Finally, on sites 9 to 12 we looked for charcoals on all uprooted-tree mounds present in the 1ha area centered on the pit. The latter method was chosen because it is a quick way to get qualitative information on the sites that were not fully investigated.

\section{Charcoal extraction and identification}

Pit profile samples and auger cores were water-sieved to recover charcoal fragments in a 4-mm mesh. This size has been estimated as the optimal minimum for anatomical identification of both temperate and tropical taxa (Chabal et al. 1999; Scheel-Ybert 2001). The charcoal fragments were then air-dried away from direct sunlight to prevent them from bursting. In the lab, charcoal fragments were broken by hand and the anatomy was observed with a reflected light dark field/bright field microscope. Identification was performed with the help of an electronic identification key (Bodin et al. 2019), the InsideWood online database (Wheeler 2011), wood anatomy atlases (Détienne et al. 1982; Détienne and Jacquet 1983; Scheel-Ybert and Gonçalves 2017) and reference collections of charred wood from Brazil and French Guiana (Scheel-Ybert 2016). Anthracological diagrams were constructed with the Excel macro ACACIA (Nourissier and Nocus unpublished).

\section{Radiocarbon dating}

Identified charcoal fragments were used for dating. Only fragments belonging to strictly different taxa (and when possible, belonging to the most abundant taxa) were selected to avoid dating the same individual (Carcaillet and Talon 1996). Following this recommendation, each $10-\mathrm{cm}$ layer was dated when possible. The 
dating was performed at the Poznań radiocarbon laboratory (Poland). The calibration was done using the IntCal13 calibration curve (Reimer et al. 2013) with the OxCal 4.3 program (Bronk Ramsey 2009). To determine if there were several periods of occupations and if they were contemporaneous among sites, we estimated kernel densities by using the mean calibrated ages with the geom_density function from the ggplot2 package (Wickham 2016). We also ran the function with calibrated dates from other sites from French Guiana (van den Bel 2015 and references therein) and from other parts of Amazonia (Heckenberger et al. 1999, 2003; Neves et al. 2004; McMichael et al. 2011, 2012; Schaan et al. 2012; Carson et al. 2014) to compare our distributions with those from previously studied archaeological sites.

\section{Data analysis}

To determine if there were site-taxa association patterns, we performed a nonmetric multidimensional scaling (nMDS) on a site-by-taxa matrix (10 sites and 104 taxa) with the metaMDS function from the vegan package (Oksanen et al. 2019). We then ran the nMDS excluding the 2 poorest sites that are likely to behave as outliers. We used the Morisita-Horn index, which handles different sample sizes, and kept in the final run $k=2$ dimensions and try=30 iterations. The analyses were performed with $\mathrm{R}$ version 3.5.0 (R Core Team 2018).

\section{Results}

\section{Radiocarbon dating}

Most of the 51 dates range between ca. 2,000 and 300 cal BP (ESM Table 1). There is a relatively good age-depth relationship despite some inversions (ESM

Fig. 1). Site 10 displays two dates around 2,500 cal BP, and only sites 2 and 3 contained very old charcoals compared to the rest of the dataset, dated to ca. 8,000 and 6,400 cal BP, respectively. Fig. 3 displays the distribution of all the mean calibrated dates. Over the last 2,000 years, our dates form a bimodal curve and seem to be divided into two main periods: a first one between ca. 1,300 and 1,000 cal BP and a second one between ca. 600 and $400 \mathrm{cal} \mathrm{BP}$ (dashed box). Sites 11 and 12 each present a single date included in this 1,700-year temporal window, 
hence they were not drawn by the geom_density function. Site 7 shows a different tendency with two dates between ca. 1,800 and 1,700 cal BP.

\section{Anthracological data}

The total number of identifiable taxa (i.e. including indeterminate charcoal types) and the total number of charcoal pieces analyzed (i.e. including the indeterminate ones whose anatomical structures are too degraded) for each site are summarized in Table 2. The anthracological diagrams are shown in the ESM Figs. 2-9 and Tables 2-3. Following Dotte-Sarout (2017), the securely identified taxa were merged with their 'cf.' analogs (e.g. Goupia glabra was merged with cf. Goupia glabra. As expected, the poorest sites in terms of taxonomic diversity are those with the lowest number of charcoal fragments. Indeed, there is a positive relationship between the total number of charcoal fragments and the number of identifiable taxa (Spearman test: $r h o=0.83$, p-value $=0.0056)$. The richest levels were always those between 0 and $30 \mathrm{~cm}$ depth; below this depth, charcoals became rare in all sites. The levels ' $10-20 \mathrm{~cm}$ ' of sites 1 and 2 are the most informative but still, they do not contain enough charcoal fragments to be considered from a quantitative point of view. For this reason, all the charcoal assemblages are represented as presence/absence in the diagrams.

\section{Ordination of the sites containing charcoal}

The sites seem to be ordered in two distinct groups following their geographical location, with those from Saut Pararé on one side and those from Inselberg on the other side (stress=0.10; Fig. 4a). This partitioning is even clearer when excluding the charcoal-poor sites 7 and 12, which are likely to behave as outliers (stress=0.08; Fig. 4c). Each time, observed dissimilarities and ordination distances are highly correlated as evidenced by the Shepard diagrams (non-metric fits $=0.989$ and 0.993, respectively; Figs. $4 \mathrm{~b}$ and d).

\section{Discussion}

\section{A bimodal distribution of ages}

In most of our sites, i.e. sites 1, 2, 3, 6, 9 and 10, we observe a bimodal distribution of the calibrated dates. We consider the dates from site 8 as part of the 
most recent mode of site 3 , because they belong to the same entity, which is the ring-ditched hill. Considering periods arbitrarily separated by at least 100 years without a date, we obtain two main periods in which $66.7 \%$ of our calibrated dates are distributed: $39.2 \%$ range between ca. 600 and 400 cal BP and $27.5 \%$ range between ca. 1,300 and 1,000 cal BP. The dates of this latter phase correspond to a period of human occupation formerly identified in the Nouragues area by Tardy (1998) between ca. 1,300 and 1,000 BP. The most recent dates probably correspond to the occupation by the Norak (or their immediate ancestors), since they disappeared from the area only 100 to 150 years later. The modes are quite consistent between the sites, suggesting two periods of human occupation over the whole Nouragues area, and the reuse/reoccupation of the anthropogenic sites. Interestingly, such bimodality is often observed in archaeological sites in French Guiana, showing the repetitiveness of the occupations (e.g. Mestre and Delpech 2008; Mestre et al. 2013; van den Bel 2015). Our dates are also consistent with those from other pre-Columbian sites from French Guiana (McKey et al. 2010; Mestre et al. 2013; van den Bel 2015 and references therein) or from elsewhere in Amazonia (e.g. Heckenberger et al. 1999, 2003; Neves et al. 2004; McMichael et al. 2011, 2012; Schaan et al. 2012), which mostly span the last 2,500 years, hence reinforcing the assumption of the anthropogenic origin of the fires (McMichael and Bush 2019).

The fact that the bimodality is also observed for site 6 is quite surprising, as it does not show many signs of past human occupation (no potsherds, high canopy forest, sparse understory, rarity of useful keystone tree species). But its location may give an explanation: sites 6 and 7 are located on opposite slopes of the same hill, which was once heavily occupied as evidenced by the presence of a piece of ceramic cassava dish on the hilltop, the "dark soil" in site 7 full of ceramic remains and the abundance of edible palms. It is unlikely that site 6 received charcoals by colluvium or as dump material from the hilltop, because of the distance of several hundreds of metres from site 7 and because the age-depth relationship remains coherent. Although it seems clear that it was subjected to some kind of clearing and burning, the lack of archaeological evidence suggests that it was neither for dwelling nor for permanent food production sensu Piperno and Pearsall (1998). In the absence of other indications, we can only hypothesize 
that it was used for temporary food production, i.e. without the intense soil modifications that led to the formation of ADE.

On the other hand, we cannot be sure that the two oldest dates from sites 2 and 3, ca. 8,000 and 6,000 cal BP respectively, relate to natural fires. Archaeological evidence older than 2,000 BP is scarce in French Guiana, and particularly in the dense forests of the interior, which are much less investigated (e.g. Mazière and Mazière 1994; Jérémie and Mestre 1997; Mestre et al. 2013). This is why charcoals older than 2,000 BP recovered from forest soils without archaeological remains are often attributed to natural fires (Charles-Dominique et al. 1998; Tardy 1998; Tardy et al. 2000). Indeed, our two oldest dates coincide with palaeofires recorded between 10,000 and 8,000 $\mathrm{BP}$ and between 6,000 and 4,000 $\mathrm{BP}$ in French Guiana (Tardy 1998; Tardy et al. 2000). However, archaeological excavations on coastal sites revealed human occupations dating back to the archaic age, ca. 6,000 cal BP on the Eva 2 site (van den Bel et al. 2006) and ca. 7,000 cal BP on a pre-ceramic site at Plateau des Mines (Mestre and Delpech 2008), thereby showing that at least one of our oldest dates (ca. 6,000 cal BP, site 3 ) is not incompatible with ancient pre-Columbian settlements.

The consistent age-depth relationship of our charcoal data suggests that the soil was not much mixed or reworked in depth after the first periods of occupation. For site 2, this means that the presence of our oldest charcoal material in the 20 $\mathrm{cm}$ depth layer is probably due to natural pedoturbation (Carcaillet and Talon 1996; Théry-Parisot et al. 2010), as the location of the site on a hilltop excludes colluvium. On the contrary, the oldest charcoals found at $30 \mathrm{~cm}$ depth on site 3 may be due either to bioturbation or to colluvium from the hilltop. Another source of pedoturbation are the tree windfalls that are common in the Nouragues forest. When trees are uprooted, this can cause the mixing of soil charcoals.

\section{Vegetation cover and wood selection and uses}

First of all, it is important to stress that given the low taxonomic diversity found in our charcoals, the assemblages cannot be considered representative of the past floristic diversity of the sites. Therefore, our anthracological spectra are discussed below from a qualitative point of view. It is challenging to determine whether the taxa identified from charcoal reflect a secondary or a mature forest because of some uncertainties: many of the identifications are restricted to the family level or 
are defined as charcoal types. Nevertheless, some taxa are of particular interest for palaeoenvironmental interpretation, when they are associated within the same sampling level. The most important are pioneer (either short- or long-lived) and heliophilic taxa. In addition, the usefulness of some taxa can provide insights into past wood management.

The upper levels corresponding to the second period of occupation, roughly between ca. 600 and $400 \mathrm{cal} \mathrm{BP}$, were richer in charcoals than the deepest levels, corresponding to the first period of occupation between ca. 1,300 and 1,000 cal BP. As a result, an interpretation of these older deposits is tricky, but the anthracological records from the most recent period of occupation give interesting insights. The fruit tree Spondias mombin was found in sites 1, 2, 3 and 9. It is dated to ca. $384 \mathrm{cal}$ BP on site 2 and was found in the upper soil layers (between 0 and $30 \mathrm{~cm}$ ) on sites 1 and 9. S. mombin is a fast-growing species, which multiplies easily in open areas, and is particularly frequent in anthropogenic ones, but disappears relatively quickly as the forest ages. The presence of this species may reflect the re-opening of previously occupied places (Balée 1994; Junqueira et al. 2011). The consistency of the age-depth relationship suggests that the presence of this species in these layers corresponds to the second period of occupation. Goupia glabra, a (long-lived) pioneer, was found in the same layer as S. mombin in site 1 and Cecropia (short-lived pioneers), dated to ca. $525.5 \mathrm{cal} \mathrm{BP}$, was found in site 3. These taxa were found in association with other pioneer or heliophilic taxa that are Melastomatoideae in site 1,2 and 3 or Hieronyma alchorneoides in site 1,2 and 9. This supports the hypothesis that secondary vegetation was present on these sites or in their vicinities during these periods. These dates are consistent with events of forest openings identified by the analysis of seeds and pollen in the Nouragues reserve by Charles-Dominique et al. (1998) and Ledru (2001). Hence, the secondary vegetation could have been present prior to the human settlements, but it is also very likely that the human activities induced or at least favored this kind of vegetation, as hypothesized before (Charles-Dominique et al. 1998; Ledru 2001; Tardy et al. 2000). The notable consistency of the two main periods of occupation found in our study with those of the forest openings in the Nouragues described by these authors are in favor of this hypothesis.

This study does not allow us to determine whether the charcoal we recovered was intentionally produced and then incorporated into the soil, or whether it resulted 
from fires set to clear the areas, or both. Nevertheless, we have found several taxa that are used for construction, crafts or as firewood by present-day Amerindian populations of French Guiana (Ogeron et al. 2018; Odonne et al. 2019). For example, Cupania/Matayba is the most frequent taxon in our charcoal assemblages: it was found in $7.2 \%$ of the sampling points, i.e. auger cores, pits or uprooted-tree mounds (Saut Pararé area: 170 sampling points; Inselberg area: 109 sampling points). Some Cupania and Matayba species, such as Cupania scrobiculata or Matayba inelegans, are used as firewood by some present-day Amerindian populations of French Guiana, but also as timbers or for craft (Odonne et al. 2019). For the Teko of the Tupí-Guaraní language family, and one of the six indigenous peoples of French Guiana, the presence of Cupania scrobiculata also testifies to a good soil for a slash-and-burn cultivation (Damien Davy personal communication), while it is still frequently used as roundwood for construction purposes by the Palikur (of the Arawak linguistic family). Other taxa found in our charcoal records give valuable wood, such as Dicorynia guianensis, Goupia glabra and Hieronyma alchorneoides, or edible fruits such as Spondias mombin, Caryocar glabrum, C. villosum and Eugenia patrisii, which are commonly used among today's Amerindian peoples. It is interesting to note that $S$. mombin, widely used among today's Amerindian peoples, is now found almost exclusively, at least in French Guiana, near villages and in the neighboring secondary forests where the fruits are harvested (Hoff and Cremers 2005; Pierre Grenand personal communication). The presence of valuable wood in the charcoal assemblages could be explained if it results from the production of charcoal from the residues of the felling of such species or from the dispersal of waste material used as fuel in a domestic context, as suggested by Scheel-Ybert et al. (2014). The latter explanation could stand as well for the presence of edible species in the assemblages, as it is the case nowadays with Spondias mombin and Eugenia patrisii (Pierre Grenand personal communication). Hence, at least some charcoals of useful species recovered in the assemblages may come from domestic fires. The most frequent taxa in our assemblages do not necessarily match those of the floristic inventories. For example, the Meliaceae, which is the most abundant family in the Saut Pararé area, is nearly absent from the charcoal record. On the other hand, we found charcoal remains of Spondias mombin in four sites, whereas this species is very rare in the present-day vegetation (only one individual out of 
17,000 trees on the 331 -ha forest plots inventoried to date in the Nouragues Research Station as part of various research programs). The fact that the relative abundances of charcoal taxa differ from those in the current flora, in addition to the presence of useful taxa, could reflect the selection of some species for charcoal production, as suggested above. Archaeological studies of the investigated sites are needed to further discuss this hypothesis. But wood preferences could also have depended on the vegetation composition. This is suggested by the pattern of anthracological assemblages (see Fig. 4c), which is consistent with what is observed in the present-day vegetation. There is indeed a difference in the floristic composition between the two areas, particularly with regard to the dominant families (Poncy et al. 2001). Obviously, these ordinations should be seen as trends emerging from exploratory anthracological results. More representative assemblages are required to confirm this pattern.

Overall, what emerges from our anthracological results is that the majority of our sites were forested before the arrival of human groups. Of those that have been clearly occupied, almost all are forested again, except sites 1 and 9, which are now covered with Lasiacis ligulata and lianas, respectively. How to explain these different trajectories?

\section{Bamboo thickets and liana forests as remnants of past human activities?}

The origin of bamboo patches sensu lato (i.e. either Lasiacis- or Guaduadominated) occurring in the forests of French Guiana is not known, but an anthropogenic origin is suggested (Gasc and Sastre 1978; Tardy 1998). In site 1, the presence of potsherds, the dark-brown color of the soil and our anthracological data are in favor of this anthropogenic hypothesis. Charcoal assemblages of site 1 gave forest taxa, contrasting with the current Lasiacis-dominated vegetation. The

${ }^{14} \mathrm{C}$ dates show that this Lasiacis patch is no older than ca. 400-300 cal BP and therefore that it established after the human occupation. Only considering the pit, that is to say a single sampling point, we found nearly 40 taxa. The location of the site on a hilltop excludes the input of charcoal by colluvium. This suggests that there was a spreading of charcoals coming from a great number of taxa in this site. This could correspond to the slashing and the burning prior to cultivation or to a random gathering of firewood in a domestic context (Fernandes Caromano et al. 
2013; Scheel-Ybert et al. 2014). In contrast, natural fires tend to produce taxonomically poor charcoal levels, even in environments with high floristic diversity (Scheel-Ybert et al. 2003; Scheel-Ybert 2004) and monospecific charcoal lenses as trees burn where they stand (Tardy 1998). Furthermore, Lasiacis ligulata has been cited as an invasive species of slash-and-burn cultures in French Guiana (Gély 1984) and several species of Lasiacis have been observed in secondary vegetation plots growing after cultivation in a tropical evergreen forest in Mexico (Castro-Luna et al. 2011). For all these reasons, we suggest that this bamboo patch may have been a permanent farming plot created after deforestation and burning, and then probably enriched several times with charcoal (Denevan 2006).

On the other hand, we found no potsherds nor charcoal fragments in site 5, which is also under a Lasiacis thicket. Hence, whereas some bamboo thickets may result from fallows or burning practices, as suggested by our results from site 1 and by other scholars previously (Sombroek 1966; Balée 1989), others may have developed as a result of natural disturbances or advantageous edaphic, topographic or climatic conditions. Hence, a landslide is probably at the origin of the bamboo patch of site 5, which is situated on a steep slope, as has often been observed in French Guiana (Sabatier and Prévost 1989; de Granville 1990). The origin of such bamboo formations could be further determined with a multi-proxy approach, integrating for example the analysis of phytoliths which, once dated, would allow the assessment of the age of these formations in the absence of charcoals (McMichael et al. 2013).

This assumption makes sense for another peculiar vegetation type found in Amazonia, which is the liana forest. Like bamboos, lianas take advantage of disturbances to spread out and prevent forest regeneration (Tymen et al. 2016). Balée and Campbell (1990) suggested that liana forests may be "recovering from past disturbance, very likely fire" and may be remnants of past cultures (see also Balée 2013). Site 9, now covered by a dense liana forest, is undoubtedly anthropogenic, as shown by the presence of a circular ditch and potsherds in the soil. As in site 1, we found many charcoal taxa of which 25 were found in the pit alone, their dates ranging from ca. 1,240 to $320 \mathrm{cal}$ BP. These taxa reflect a dense forest cover, contrasting with the current liana dominance, meaning that these latter would have invaded afterwards. Interestingly, Tardy (1998) also found 
forest taxa in the charcoal assemblage coming from another liana forest in the Inselberg area, dated to 1,063-799 cal BP, which corresponds to the chronology of site 9.

The anthracological results of site 9 make it comparable to site 1: in both cases, we observe a contemporary "loss of diversity" subsequent to a human disturbance, with the transition from a dense forest to a bamboo thicket in one case and to a liana forest in the other in the same period, starting from ca. 400-300 cal BP. For now, the anthracological study does not allow us to infer the type of occupation or land use on the anthropogenic sites, and our results for a single liana forest (site 7 being too charcoal-poor) cannot be generalized to all liana patches. The fact that sites 1 and 9 are now covered by Lasiacis and lianas, respectively, but also that some sites, such as the ring-ditched hill, are still under forest cover following a human occupation, may result from different utilizations of the sites. The difference in the nature (and intensity) of human activities may have led to distinct vegetation regeneration pathways after abandonment, some leading to an ecological tipping point with the installation of bamboos or vines that block the natural forest regeneration. It has been suggested that the type of anthrosol may reflect the type of occupation: the black, ceramic-rich terra preta is associated with ancient villages, whereas the brownish, ceramic-poor terra mulata is associated with ancient cultivated areas (e.g. Sombroek 1966; Woods and McCann 1999; Sombroek et al. 2002; Denevan 2006; Glaser 2007). In French Guiana, anthrosols are not as dark and thick as the terra preta found in many Brazilian locations: a preliminary micromorphological study by Brancier et al. (2014) revealed that their structure and content are closer to the terra mulata, yet still different. Therefore, French Guiana dark soils may be part of a continuum between terra preta and terra mulata, as proposed by Fraser et al. (2011), and anthrosols should not be categorized in such a dichotomous way. Hence, it remains difficult to assess the origin of the anthrosols of French Guiana under forest cover.

\section{Conclusions}

These first anthracological results have revealed that the Nouragues Reserve experienced two main periods of occupation between ca. 1,300 and 1,000 cal BP and between ca. 600 and $400 \mathrm{cal}$ BP and that pre-Columbian human activities had 
a radically different impact on the vegetation depending on the site. The most recent dates suggest that at a Lasiacis thicket and a liana forest developed after indigenous settlements or land management ceased, and that important shifts in the forested vegetation can occur as a consequence of past human occupation. Evidence suggests that this Lasiacis thicket could have developed on an abandoned farming plot. Nevertheless, another Lasiacis thicket did not show any anthropogenic clue, suggesting that some probably have a natural origin. Other sites, clearly anthropogenic, such as the ring-ditched hill, did not experience such profound vegetation change. This suggests that the change in the vegetation structure, the composition and the resilience of the forest may depend on the type of activity (dwelling, ceremonial, farming or other). In several sites, charcoal assemblages contained secondary forest taxa suggesting that there was an opening of the forest or that it was kept in this state during the occupation. Finally, the presence of useful species in the assemblages suggests a wood selection for charcoal production, which could have been adapted depending on the local vegetation composition.

Acknowledgements This study is part of the LongTIme project (Long Term Impact of ancient Amerindian settlements on Guianese forests). We acknowledge an Investissement d'Avenir grant from the Agence Nationale de la Recherche (CEBA: ANR-10-LABX-25$01)$. We are very grateful to all the people who helped on the field with the digging and the carrying of large amounts of sediment across the forest: Christol Docquier, Florian Jeanne, Jean-Louis Smock, Marc-Alexandre Tareau, Michel Rapinski, Mickaël Ayanne, Mélanie Roy and Tanguy Leblanc. We also thank Laure Paradis for the creation of Fig. 1, Maxime Réjou-Méchain for discussions on multivariate analyses, and Michel Brossard, Mickaël Mestre and Damien Davy for their helpful comments on a previous version of the manuscript. Finally, we thank Frédéric Fernandez from the Analytical Microscopy Platform of the University of Montpellier for the SEM pictures and Tomasz Goslar from the Poznań Radiocarbon laboratory. We thank the Nouragues Nature Reserve and the Nouragues research field station (managed by CNRS). The latter benefits from "Investissement d'Avenir" grants managed by Agence Nationale de la Recherche (AnaEE France ANR-11-INBS-0001; Labex CEBA ANR-10-LABX-25-01).

\section{References}


Balée W (1989) The culture of Amazonian forests. Adv Econ Bot 7:1-21

Balée W (1993) Indigenous Transformation of Amazonian Forests: An Example from Maranhão, Brazil. L'Homme 33:231-254. https://doi.org/10.3406/hom.1993.369639

Balée W (1994) Footprints of the forest: Ka'apor ethnobotany - the historical ecology of plant utilization by an Amazonian people. Columbia University Press, New York

Balée W (2013) Cultural Forests of the Amazon: A Historical Ecology of People and Their Landscapes. University of Alabama Press, Tuscaloosa

Balée W, Campbell DG (1990) Evidence for the Successional Status of Liana Forest (Xingu River Basin, Amazonian Brazil). Biotropica 22:36-47. https://doi.org/10.2307/2388717

Barlow J, Gardner TA, Lees AC, Parry L, Peres CA (2012) How pristine are tropical forests? An ecological perspective on the pre-Columbian human footprint in Amazonia and implications for contemporary conservation. Biol Conserv 151:45-49. https://doi.org/10.1016/j.biocon.2011.10.013

Bodin SC, Scheel-Ybert R, Beauchêne J, Molino J-F, Bremond L (2019) CharKey: An electronic identification key for wood charcoals of French Guiana. IAWA J 40:75-91

Bongers F, Charles-Dominique P, Forget P-M, Théry M (2013) Nouragues: Dynamics and Plant-Animal Interactions in a Neotropical Rainforest. Springer, Dordrecht

Brancier J, Cammas C, Todisco D, Fouache E (2014) A Micromorphological Assessment of Anthropogenic Features in Pre-Columbian French Guiana Dark Soils (FGDS): First Results. Z Geomorphol Suppl Issues 58:109-139. https://doi.org/DOI: 10.1127/0372-8854/2014/S-00159

Bronk Ramsey C (2009) Bayesian Analysis of Radiocarbon Dates. Radiocarbon 51:337-360. https://doi.org/10.1017/S0033822200033865

Carcaillet C, Talon B (1996) Aspects taphonomiques de la stratigraphie et de la datation de charbons de bois dans les sols: exemple de quelques sols des Alpes. Géogr Phys Quat 50:233-244. https://doi.org/10.7202/033091ar

Carson JF, Whitney BS, Mayle FE, Iriarte J, Prümers H, Soto JD, Watling J (2014) Environmental impact of geometric earthwork construction in pre-Columbian Amazonia. Proc Natl Acad Sci USA 111:10,497-10,502. https://doi.org/10.1073/pnas.1321770111

Castro-Luna AA, Castillo-Campos G, Sosa V (2011) Effects of selective logging and shifting cultivation on the structure and diversity of a tropical evergreen forest in south-eastern Mexico. J Trop For Sci 23:17-34

Chabal L, Fabre L, Terral JF, Théry-Parisot I (1999) L'anthracologie. In: Bourquin-Mignot C et al (eds) La botanique. Errance, Paris, pp 43-104

Charles-Dominique P, Blanc P, Larpin D et al (1998) Forest perturbations and biodiversity during the last ten thousand years in French Guiana. Acta Oecol 19:295-302. https://doi.org/10.1016/S1146-609X(98)80033-7

Clement CR, de Cristo-Araújo M, Coppens D’Eeckenbrugge G, Alves Pereira A, Picanço-Rodrigues D (2010) Origin and Domestication of Native Amazonian Crops. Diversity 2:72-106.

https://doi.org/10.3390/d2010072

Clement CR, Denevan WM, Heckenberger MJ, Junqueira AB, Neves EG, Teixeira WG, Woods WI (2015) The domestication of Amazonia before European conquest. Proc R Soc B Biol Sci 282:20150813. https://doi.org/10.1098/rspb.2015.0813 
De Granville J-J (1990) Les formations végétales primaires de la zone intérieure de Guyane. ORSTOM, Cayenne

De Souza JG, Schaan DP, Robinson M et al (2018) Pre-Columbian earth-builders settled along the entire southern rim of the Amazon. Nat Commun 9:1125. https://doi.org/10.1038/s41467-018-03510-7

Denevan WM (1992) The Pristine Myth: The Landscape of the Americas in 1492. Ann Assoc Am Geogr $82: 369-385$

Denevan WM (2006) Pre-European forest cultivation in Amazonia. In: Balée W, Erickson CL (eds) Time and Complexity in Historical Ecology: Studies in the Neotropical Lowlands. Columbia University Press, New York, pp 153-163

Détienne P, Jacquet P (1983) Atlas d'identification des bois de l'Amazonie et des régions voisines. Centre Technique Forestier Tropical, Nogent-Sur-Marne

Détienne P, Jacquet P, Mariaux A (1982) Manuel d'identification des bois tropicaux. Tome 3: Guyane française. Centre Technique Forestier Tropical, Nogent-Sur-Marne

Dotte-Sarout E (2017) Evidence of forest management and arboriculture from wood charcoal data: an anthracological case study from two New Caledonia Kanak pre-colonial sites. Veget Hist Archaeobot 26:195211

Erickson C, Balée W (2006) Time and Complexity in Historical Ecology: Studies in the Neotropical Lowlands. Columbia University Press, New York

Fernandes Caromano C, Cascon LM, Neves EG, Scheel-Ybert R (2013) Revealing Fires and Rich Diets:

Macro- and Micro-archaeobotanical Analysis at the Hatahara Site, Central Amazonia. Tipití J Soc Anthropol Lowl S Am 11:40-51

Fraser J, Teixeira W, Falcão N, Woods W, Lehmann J, Junqueira AB (2011) Anthropogenic soils in the Central Amazon: from categories to a continuum. Area 43:264-273. https://doi.org/10.1111/j.14754762.2011.00999.x

Gasc JP, Sastre C (1978) Les formations ouvertes à graminées bambusiformes (Cambrouzes) sont-elles en Guyane française le signe d'un ancien peuplement humain? 103ème Congr. Nat. Soc. Sav. Nancy, pp 97-103 Gély A (1984) L'agriculture sur brûlis chez quelques communautés d'amérindiens et de noirs réfugiés de Guyane française. J Agric Tradit Bot Appliquée 31:43-70. https://doi.org/10.3406/jatba.1984.3912

German L (2001) The dynamics of terra preta: An integrated study of human-environmental interactions in a nutrient-poor Amazonian ecosystem. PhD thesis, University of Georgia, Athens

German L (2003) Ethnoscientific Understandings of Amazonian Dark Earths. In: Lehmann J, Kern DC, Glaser B, Wodos WI (eds) Amazonian Dark Earths: Origin Properties Management. Springer, Dordrecht, pp 179-201

Glaser B (2007) Prehistorically modified soils of central Amazonia: a model for sustainable agriculture in the twenty-first century. Philos Trans R Soc B Biol Sci 362:187-196. https://doi.org/10.1098/rstb.2006.1978

Glaser B, Birk JJ (2012) State of the scientific knowledge on properties and genesis of Anthropogenic Dark Earths in Central Amazonia (terra preta de Índio). Geochim Cosmochim Acta 82:39-51.

https://doi.org/10.1016/j.gca.2010.11.029

Grenand P (2006) Que sont devenus les Amérindiens de l'Approuague? Réflexions autour d'une histoire peu documentée. In: Mam-Lam-Fouck S, Zonzon J (eds) L'histoire de la Guyane, depuis les civilisations 
amérindiennes: Actes du Colloque des 16, 17 et 18 novembre 2005, Cayenne. Ibis Rouge, Matoury, pp 105126

Grimaldi M, Riéra B (2001) Geography and Climate. In: Bongers F, Charles-Dominique P, Forget P-M, Théry M (eds) Nouragues: Dynamics and Plant-Animal Interactions in a Neotropical Rainforest. Springer, Dordrecht, pp 9-18

Heckenberger M, Neves EG (2009) Amazonian Archaeology. Annu Rev Anthropol 38:251-266. https://doi.org/10.1146/annurev-anthro-091908-164310

Heckenberger MJ, Kuikuro A, Kuikuro UT, Russell JC, Schmidt M, Fausto C, Franchetto B (2003) Amazonia 1492: Pristine Forest or Cultural Parkland? Science 301:1,710-1,714. https://doi.org/10.1126/science. 1086112

Heckenberger MJ, Petersen JB, Neves EG (1999) Village Size and Permanence in Amazonia: Two Archaeological Examples from Brazil. Lat Am Antiq 10:353-376. https://doi.org/10.2307/971962 Heckenberger MJ, Russell JC, Toney JR, Schmidt MJ (2007) The legacy of cultural landscapes in the Brazilian Amazon: implications for biodiversity. Philos Trans R Soc Lond B Biol Sci 362:197-208

Hoff M, Cremers G (2005) Le jardin guyanais: inventaire des plantes cultivées et des adventices des jardins de Guyane française. J Bot Soc Bot France 29:3-40

Iriarte J, Glaser B, Watling J et al (2010) Late Holocene Neotropical agricultural landscapes: phytolith and stable carbon isotope analysis of raised fields from French Guianan coastal savannahs. J Archaeol Sci 37:2,984-2,994. https://doi.org/10.1016/j.jas.2010.06.016

Iriarte J, Power MJ, Rostain S et al (2012) Fire-free land use in pre-1492 Amazonian savannas. Proc Natl Acad Sci USA 109:6,473-6,478. https://doi.org/10.1073/pnas.1201461109

Jérémie S, Mestre M (1997) Présentation de la prospection archéologique réalisée sur le tracé de la future RN2, entre Regina et St Georges de l'Oyapock (Guyane française). J Soc Américanistes 83:271-277 Junqueira AB, Shepard GH, Clement CR (2010) Secondary forests on anthropogenic soils in Brazilian Amazonia conserve agrobiodiversity. Biodivers Conserv 19:1,933-1,961. https://doi.org/10.1007/s10531-0109813-1

Junqueira AB, Shepard GH, Clement CR (2011) Secondary Forests on Anthropogenic Soils of the Middle Madeira River: Valuation, Local Knowledge, and Landscape Domestication in Brazilian Amazonia. Econ Bot 65:85-99. https://doi.org/10.1007/s12231-010-9138-8

Kern DC, D’Aquino G, Rodrigues TE, Frazao FJL, Sombroek W, Myers TP, Neves EG (2003) Distribution of Amazonian Dark Earths in the Brazilian Amazon. In: Lehmann J, Kern DC, Glaser B, Woods WI (eds) Amazonian Dark Earths: Origin Properties Management. Springer, Dordrecht, pp 51-75

Ledru MP (2001) Late Holocene rainforest disturbance in French Guiana. Rev Palaeobot Palynol 115:161170. https://doi.org/10.1016/S0034-6667(01)00068-9

Lescure J-P, Boulet R (1985) Relationships between soil and vegetation in a tropical rain forest in French Guiana. Biotropica 17:155-164

Levis C, Costa FRC, Bongers F et al (2017) Persistent effects of pre-Columbian plant domestication on Amazonian forest composition. Science 355:925-931. https://doi.org/10.1126/science.aal0157 
Levis C, Figueira de Souza P, Schietti J, Emilio T, Purri da Veiga Pinto JL, Clement CR, Costa FRC (2012) Historical Human Footprint on Modern Tree Species Composition in the Purus-Madeira Interfluve, Central Amazonia. PLoS ONE 7:e48559. https://doi.org/10.1371/journal.pone.0048559

Mazière M, Mazière G (1994) L'archéologie amérindienne en Guyane. Etat actuel de la recherche. Bull Soc Préhist France 91:333-341. https://doi.org/10.3406/bspf.1994.9742

McKey D, Rostain S, Iriarte J, Glaser B, Birk JJ, Holst I, Renard D (2010) Pre-Columbian agricultural landscapes, ecosystem engineers, and self-organized patchiness in Amazonia. Proc Natl Acad Sci USA 107:7,823-7,828. https://doi.org/10.1073/pnas.0908925107

McMichael CNH, Bush MB (2019) Spatiotemporal patterns of pre-Columbian people in Amazonia. Quat Res 92:53-69. https://doi.org/10.1017/qua.2018.152

McMichael CH, Bush MB, Piperno DR, Silman MR, Zimmerman AR, Anderson C (2011) Spatial and temporal scales of pre-Columbian disturbance associated with western Amazonian lakes. Holocene 22:131141. https://doi.org/10.1177/0959683611414932

McMichael CH, Bush MB, Silman MR et al (2013) Historical fire and bamboo dynamics in western Amazonia. J Biogeogr 40:299-309. https://doi.org/10.1111/jbi.12002

McMichael CH, Palace MW, Bush MB et al (2014) Predicting pre-Columbian anthropogenic soils in Amazonia. Proc R Soc B Biol Sci 281:20132475. https://doi.org/10.1098/rspb.2013.2475

McMichael CH, Piperno DR, Bush MB, Silman MR, Zimmerman AR, Raczka MF, Lobato LC (2012) Sparse Pre-Columbian Human Habitation in Western Amazonia. Science 336:1,429-1,431.

https://doi.org/10.1126/science. 1219982

Mestre M, Delpech S (2008) «Plateau des Mines » Saint-Laurent du Maroni. Rapport de Fouilles. INRAP, Cayenne

Mestre M, Delpech S, Hildebrand M (2013) Yaou. Rapport de diagnostic. Inrap, Service Régional de l'Archéologie, Cayenne

Molino J-F, Sabatier D (2001) Tree Diversity in Tropical Rain Forests: A Validation of the Intermediate Disturbance Hypothesis. Science 294:1,702-1,704

Neves EG, Petersen JB, Bartone RN, Heckenberger MJ (2004) The Timing of Terra Preta Formation in the Central Amazon: Archaeological Data from Three Sites. In: Glaser B, Woods WI (eds) Amazonian Dark Earths: Explorations in Space and Time. Springer, Berlin, Heidelberg, pp 125-134

Odonne G, van den Bel M, Burst M et al (2019) Long-term influence of early human occupations on current forests of the Guiana Shield. Ecology 100:e02806. https://doi.org/10.1002/ecy.2806

Ogeron C, Odonne G, Cristinoi A et al (2018) Palikur traditional roundwood construction in eastern French Guiana: ethnobotanical and cultural perspectives. J Ethnobiol Ethnomed 14:28.

https://doi.org/10.1186/s13002-018-0226-7

Oksanen J, Blanchet FG, Friendly M et al (2019) vegan: Community Ecology Package

Oliver JR (2008) The Archaeology of Agriculture in Ancient Amazonia. In: Silverman H, Isbell WH (eds)

The Handbook of South American Archaeology. Springer, New York, pp 185-216

Peel MC, Finlayson BL, McMahon TA (2007) Updated world map of the Köppen-Geiger climate classification. Hydrol Earth Syst Sci Discuss 4:439-473 
Pélissier R, Dray S, Sabatier D (2001) Within-plot relationships between tree species occurrences and hydrological soil constraints: an example in French Guiana investigated through canonical correlation analysis. Plant Ecol 162:143-156

Piperno DR, Pearsall DM (1998) The origins of agriculture in the lowland Neotropics. Academic Press, San Diego

Piperno DR, McMichael C, Bush MB (2015) Amazonia and the Anthropocene: What was the spatial extent and intensity of human landscape modification in the Amazon Basin at the end of prehistory? Holocene 25:1,588-1,597. https://doi.org/10.1177/0959683615588374

Piperno DR, McMichael CNH, Bush MB (2019) Finding forest management in prehistoric Amazonia. Anthropocene 26:100211. https://doi.org/10.1016/j.ancene.2019.100211

Poncy O, Sabatier D, Prévost M-F, Hardy I (2001) The Lowland High Rainforest: Structure and Tree Species Diversity. In: Bongers F, Charles-Dominique P, Forget P, Théry M (eds) Nouragues: Dynamics and PlantAnimal Interactions in a Neotropical Rainforest. Springer, Dordrecht, pp 31-46

Posey DA (1985) Indigenous management of tropical forest ecosystems: the case of the Kayapo indians of the Brazilian Amazon. Agrofor Syst 3:139-158

R Core Team (2018) R: A language and environment for statistical computing. R Foundation for Statistical Computing, Vienna, Austria

Reimer PJ, Bard E, Bayliss A et al (2013) IntCal13 and Marine13 radiocarbon age calibration curves 050,000 years cal BP. Radiocarbon 55:1,869-1,887

Rostain S (1994) L'occupation amérindienne ancienne du littoral de Guyane. PhD thesis, Université Paris 1 Panthéon-Sorbonne, Paris

Rostain S (2008) The Archaeology of the Guianas: An Overview. In: Silverman H, Isbell WH (eds) The Handbook of South American Archaeology. Springer, New York, pp 279-302

Sabatier D, Prévost M-F (1989) Quelques données sur la composition floristique et la diversité des peuplements forestiers de Guyane française. Bois For Trop 219:31-55

Sabatier D, Grimaldi M, Prévost M-F, Guillaume J, Godron M, Dosso M, Curmi P (1997) The influence of soil cover organization on the floristic and structural heterogeneity of a Guianan rain forest. Plant Ecol $131: 81-108$

Sabatier D, Guitet S, Vincent G et al (2017) Forçages environnementaux et anthropiques du turnover forestier, conséquences sur la diversité des communautés d'arbres en forêt tropicale (DynForDiv). LabEx CEBA, IRD, Cayenne

Schaan D, Pärssinen M, Saunaluoma S, Ranzi A, Bueno M, Barbosa A (2012) New radiometric dates for precolumbian (2000-700 B.P.) earthworks in western Amazonia, Brazil. J Field Archaeol 37:132-142. https://doi.org/10.1179/0093469012Z.00000000012

Scheel-Ybert R (2001) Man and vegetation in southeastern Brazil during the late Holocene. J Archaeol Sci 28:471-480

Scheel-Ybert R (2004) Teoria e métodos em antracologia. 1. Considerações teoricas e perspectivas. Arq Mus Nac 62:3-14

Scheel-Ybert R (2016) Charcoal collections of the world. IAWA J 37:489-505 
Scheel-Ybert R, Gonçalves TAP (2017) Primeiro Atlas Antracológico de Espécies Brasileiras/First Anthracological Atlas of Brazilian Species. Museu Nacional, Rio de Janeiro

Scheel-Ybert R, Beauclair M, Buarque A (2014) The forest people: landscape and firewood use in the Araruama region, southeastern Brazil, during the late Holocene. Veget Hist Archaeobot 23:97-111. https://doi.org/10.1007/s00334-013-0397-z

Scheel-Ybert R, Gouveia SEM, Pessenda LCR, Aravena R, Coutinho LM, Boulet R (2003) Holocene palaeoenvironmental evolution in the São Paulo State (Brazil), based on anthracology and soil $\delta 13 \mathrm{C}$ analysis. Holocene 13:73-81. https://doi.org/10.1191/0959683603hl596rp

Sombroek WG (1966) Amazon soils: a reconnaissance of the soils of the Brazilian Amazon region. PhD thesis, Pudoc

Sombroek W, Kern D, Rodrigues T, Cravo MS, Cunha TJ, Woods W, Glaser B (2002) Terra Preta and Terra Mulata: Pre-Columbian Amazon kitchen middens and agricultural fields, their sustainability and their replication. In: Symposium 18 - Anthropogenic factors of soil formation, 17th World Congress of Soil Science. Bangkok, Thailand

Tardy C (1998) Paléoincendies naturels, feux anthropiques et environnements forestiers de Guyane Française du tardiglaciaire à l'holocène récent: Approches chronologique et anthracologique. $\mathrm{PhD}$ thesis, Université Montpellier 2, Montpellier

Tardy C, Vernet JL, Servant M et al (2000) Feux, sols et écosystèmes forestiers tropicaux. In: Servant M, Servant Vildary S (eds) Dynamique à long terme des écosystèmes forestiers intertropicaux. IRD, Paris, pp 343-348

Théry-Parisot I, Chabal L, Chrzavzez J (2010) Anthracology and taphonomy, from wood gathering to charcoal analysis. A review of the taphonomic processes modifying charcoal assemblages, in archaeological contexts. Palaeogeogr Palaeoclimatol Palaeoecol 291:142-153. https://doi.org/10.1016/j.palaeo.2009.09.016

Tymen B, Réjou-Méchain M, Dalling JW et al (2016) Evidence for arrested succession in a liana-infested Amazonian forest. J Ecol 104:149-159. https://doi.org/10.1111/1365-2745.12504

Van den Bel MM (2015) Archaeological Investigations between Cayenne Island and the Maroni River. A cultural sequence of western coastal French Guiana from 5000 BP to present. Sidestone Press, Leiden Van den Bel M, Hildebrand M, Delpech S, Romon T, Vallet C (2006) Les occupations amérindiennes du site Eva 2, Chantier Soyouz du CSG, Malmanoury. Commune de Sinnamary, Guyane Française. INRAP, Cayenne

Versteeg AH (2003) Suriname voor Columbus/Suriname before Columbus. Stichting Surinaams Museum, Paramaribo

Wheeler EA (2011) Inside wood-a web resource for hardwood anatomy. IAWA J 32:199-211

Wickham H (2016) ggplot2: Elegant Graphics for Data Analysis. Springer, New York

Woods WI, McCann JM (1999) The Anthropogenic Origin and Persistence of Amazonian Dark Earths. Yearbook (Conference of Latin Americanist Geographers) 25:7-14 


\section{Figure captions}

Fig. 1 Location of the study sites. a Location of French Guiana in South America; b Location of the Nouragues Natural Reserve and of the study area; c Location of the 12 study sites near the two base camps Saut Pararé and Inselberg. Origin of the data: DEM SRTM1 (meter a.s.1.), BDTopo IGN, NaturalEarth. L. Paradis, UMR 5554 ISEM

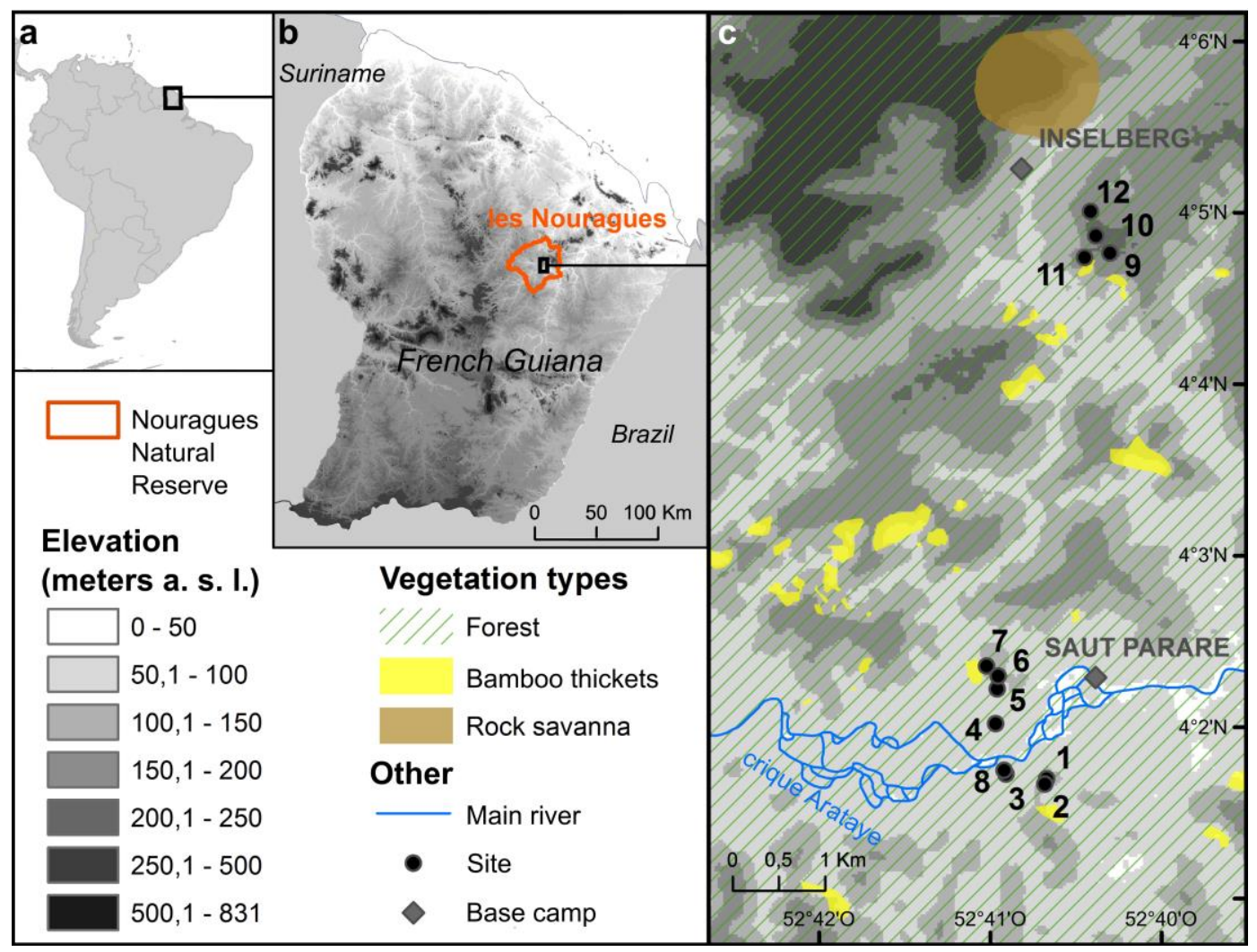

Fig. 2 Aerial photographs and digital elevation model (DEM) around the ditched sites.

a Vegetation cover centered on the ring-ditched hill. A Lasiacis thicket is visible at the bottom right corner of the picture (canopy-free area); b DEM model of the ring-ditched hill. The ditch appears as a circular ring (site 3) around the hilltop (site 8); c Vegetation cover centered on the ditched site near the Inselberg station. Two Lasiacis thickets are visible at the bottom of the picture; d DEM of the ditched site near the Inselberg station (site 9). The ditch appears on the edge of the plateau. J.-F. Molino, IRD/CNES/CEBA 


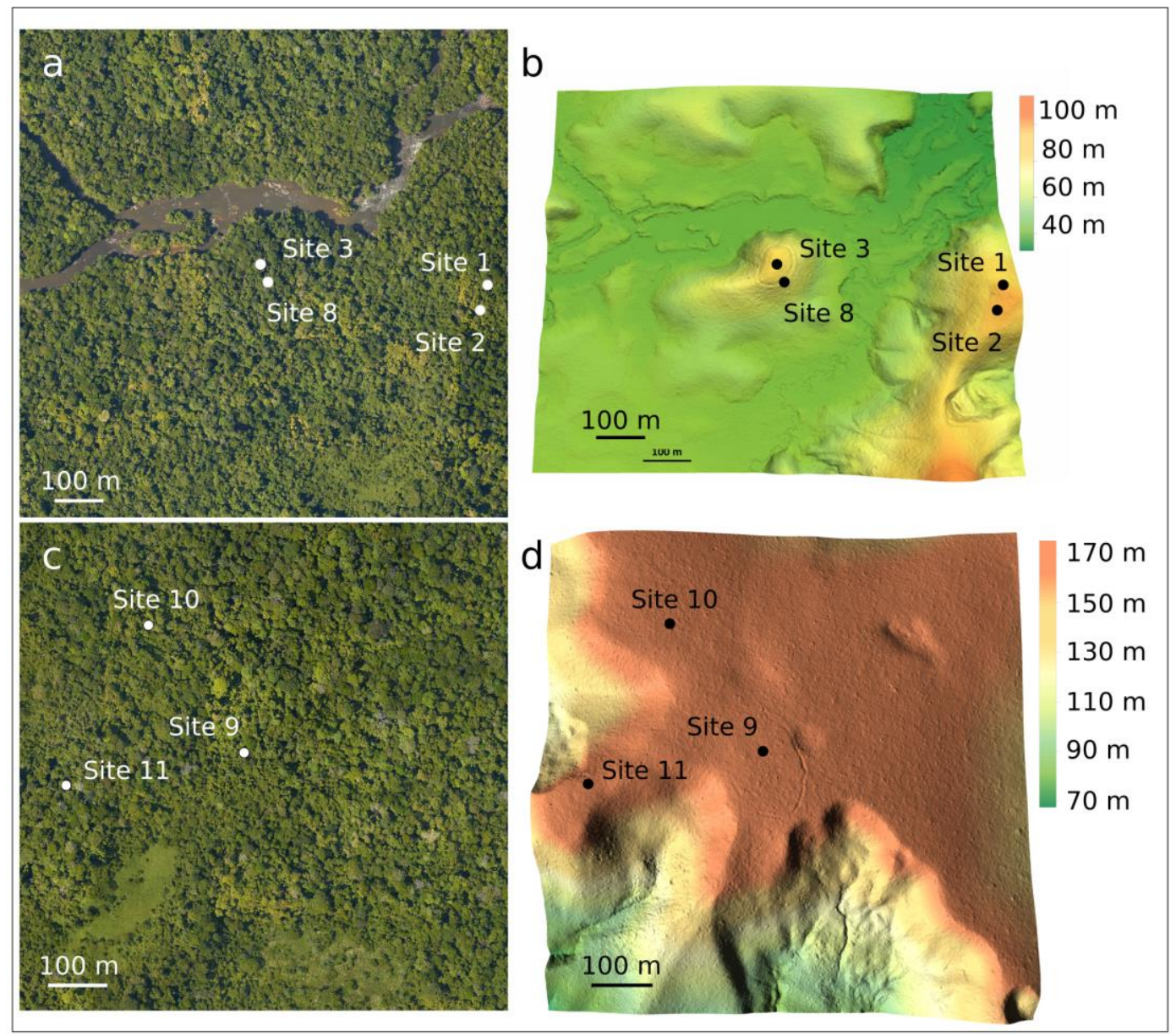

Fig. 3 Kernel densities of the mean calibrated dates per site with regard to pools of calibrated dates from other sites in French Guiana and in the rest of Amazonia. The dotted box shows the most recent dates in a 1,700-year temporal window to better visualize their distribution in this interval. The dates of sites 3 and 8 were pooled together in the dashed box to better see the distribution of the dates from the ring-ditched hill as a whole. Sites 11 and 12 are not represented in the dotted box as only one of their dates fall in its time window 


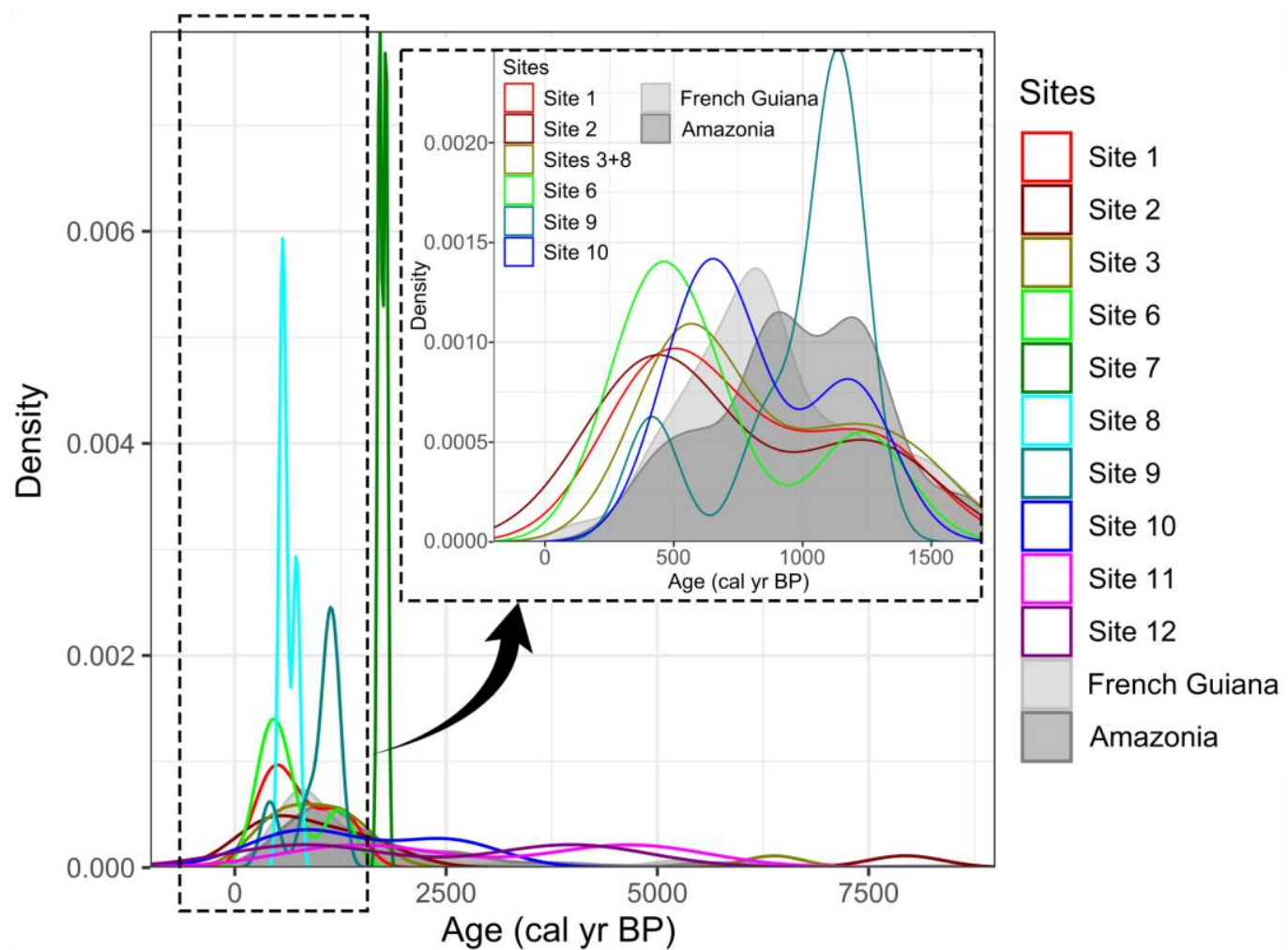

Fig. 4 Non-metric multidimensional scalings (nMDS) of the charcoal assemblages with their associated Shepard diagrams showing the goodness-of-fit of the ordinations: the sites of Saut Pararé are in red, those of Inselberg are in black. No charcoals were recovered from sites 4 and 5. a $\mathrm{nMDS}$ (stress $=0.10$ for $\mathrm{k}=2$ dimensions and 30 iterations) and $\mathbf{b}$ Shepard diagram (non-metric fit $=0.989$ ) considering all the sites containing charcoal; $\mathbf{c}$ nMDS (stress $=0.08$ for $\mathrm{k}=2$ dimensions and 30 iterations) and $\mathbf{d}$ Shepard diagram (non-metric fit=0.993) excluding the charcoal-poor sites 7 and 12
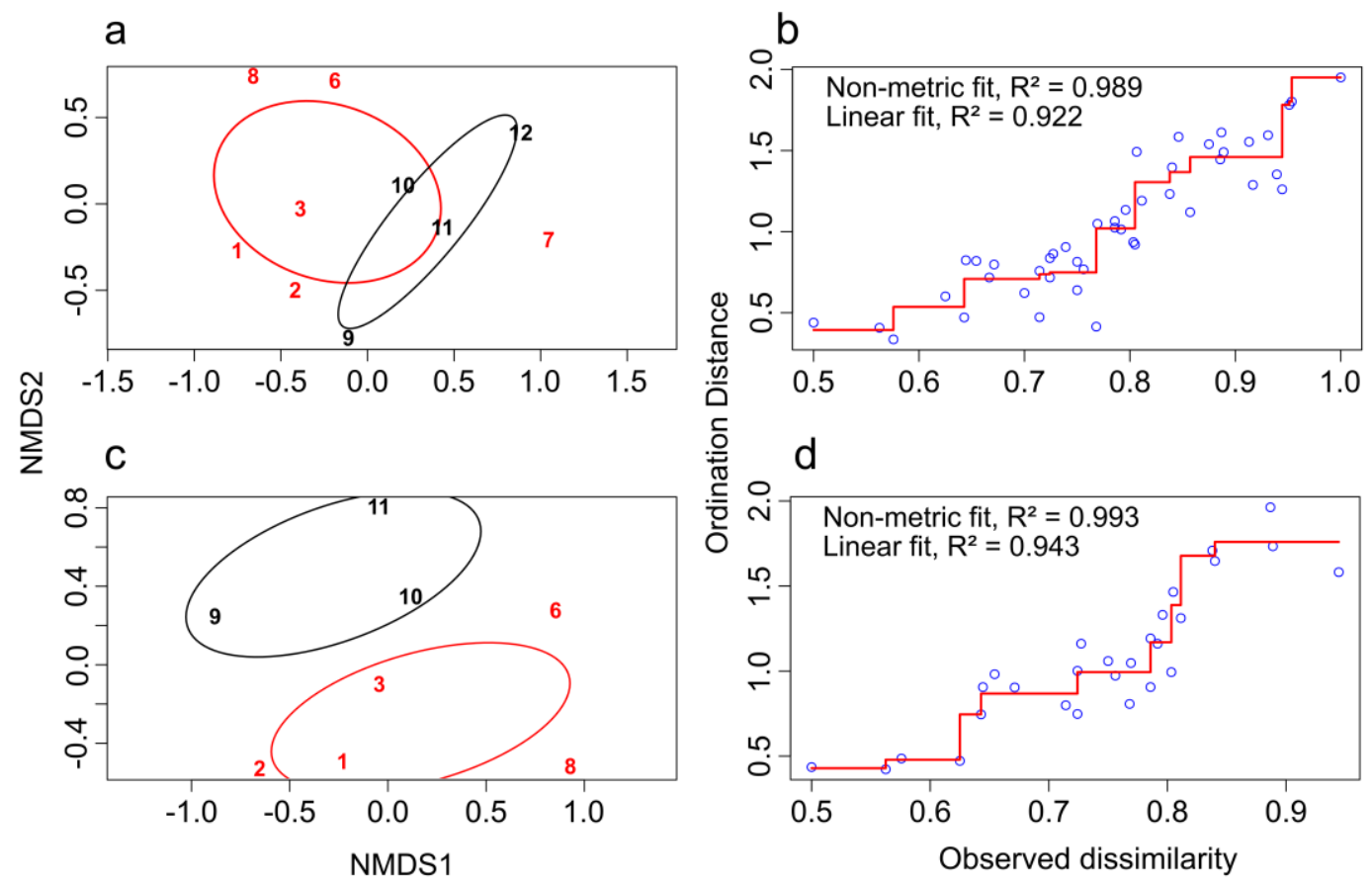
Table 1 Main features of the 12 sites investigated, with their botanical, archaeological and pedological characteristics 


\begin{tabular}{|c|c|c|c|c|c|c|c|c|c|c|c|c|c|c|}
\hline Site & Coordinates & $\begin{array}{l}\text { Plot } \\
\text { (1ha) }\end{array}$ & $\begin{array}{l}\text { Identified } \\
\text { species } \\
\text { (1ha) }\end{array}$ & $\begin{array}{l}\text { Families } \\
\text { (1ha) }\end{array}$ & $\begin{array}{l}\text { Individuals } \\
\geq 10 \mathrm{~cm} \\
\text { d.b.h. (1ha) }\end{array}$ & $\begin{array}{l}\text { Dominant/Most } \\
\text { abundant species } \\
\text { (1ha) }\end{array}$ & \begin{tabular}{|l|} 
Dominant/Most \\
abundant \\
family (1ha)
\end{tabular} & Vegetation type & Potsherds & Charcoals & Anthropog. & $\begin{array}{l}\text { Topography, } \\
\text { associated } \\
\text { earthwork }\end{array}$ & $\begin{array}{l}\text { Soil clay } \\
\text { content } \\
\left(\mathrm{g} \cdot \mathrm{kg}^{-1}\right)\end{array}$ & $\begin{array}{l}\text { Soil color, } \\
\text { (surface to } \\
\text { deep layers }\end{array}$ \\
\hline 1 & $\begin{array}{l}4.02832 ; \\
-52.67785\end{array}$ & -- & -- & -- & \begin{tabular}{|l}
-- \\
\end{tabular} & Lasiacis ligulata & Poaceae & Lasiacis thicket & Present & Present & Yes & Plateau & $650-790$ & $\begin{array}{l}\text { Dark brown } \\
\text { - yellowish } \\
\text { red }\end{array}$ \\
\hline 2 & $\begin{array}{l}4.02778 \\
-52.67803\end{array}$ & LTN1 & 116 & 38 & 544 & $\begin{array}{l}\text { Pouteria } \\
\text { gongrijpii } \\
(8.46 \%)\end{array}$ & $\begin{array}{l}\text { Meliaceae } \\
(17.10 \%)\end{array}$ & $\begin{array}{l}\text { Middle-high to high canopy } \\
\text { forest with Astrocaryum } \\
\text { paramaca in the understory }\end{array}$ & Present & Present & Yes & Plateau & $610-690$ & $\begin{array}{l}\text { Dark brow - } \\
\text { strong brown }\end{array}$ \\
\hline 3 & $\begin{array}{l}.02877 \\
-52.68182\end{array}$ & -- & -- & -- & $\begin{array}{ll}- \\
-\end{array}$ & -- & -- & -- & Present & Present & Yes & $\begin{array}{l}\text { Filled ditch } \\
\text { of the ring- } \\
\text { ditched hill }\end{array}$ & $610-780$ & $\begin{array}{l}\text { Yellowish } \\
\text { red - red }\end{array}$ \\
\hline 4 & $\begin{array}{l}4.03365 \\
-52.6828\end{array}$ & LTN2 & 93 & 42 & 487 & $\begin{array}{l}\text { Eschweilera } \\
\text { coriacea }(3.29 \%)\end{array}$ & $\begin{array}{l}\text { Leguminosae } \\
(18.07 \%)\end{array}$ & $\begin{array}{l}\text { Middle-high to high canopy } \\
\text { forest }\end{array}$ & Unobserved & Unobserved & No & $\begin{array}{l}\text { Plateau, } \\
\text { alluvial } \\
\text { terrace }\end{array}$ & $450-680$ & $\begin{array}{l}\text { Reddish } \\
\text { brown - } \\
\text { strong brown }\end{array}$ \\
\hline 5 & $\begin{array}{l}4.03705 \\
-52.68267\end{array}$ & -- & -- & -- & -- & $\begin{array}{l}\text { Lasiacis ligulatal } \\
\text { Heliconia bihai }\end{array}$ & $\begin{array}{l}\text { Poaceae/Helico } \\
\text { niaceae }\end{array}$ & Lasiacis/Heliconia thicket & Unobserved & Unobserved & No & Steep slope & $350-450$ & $\begin{array}{l}\text { Dark brown } \\
\text { - strong } \\
\text { brown }\end{array}$ \\
\hline 6 & $\begin{array}{l}4.0383 ; \\
-52.68255\end{array}$ & NPA2 & 109 & 34 & 546 & $\begin{array}{l}\text { Tetragastris } \\
\text { altissima } \\
(7.33 \%)\end{array}$ & $\begin{array}{l}\text { Burseraceae } \\
(17.03 \%)\end{array}$ & $\begin{array}{l}\text { High canopy forest, sparse } \\
\text { understory }\end{array}$ & Unobserved & Present & No & Gentle slope & $300-600$ & $\begin{array}{l}\text { Yellowish } \\
\text { brown - } \\
\text { strong brown }\end{array}$ \\
\hline 7 & $\begin{array}{l}4.03927 \\
-52.68368\end{array}$ & NPA4 & 119 & 43 & 628 & $\begin{array}{l}\text { Iryanthera } \\
\text { sagotiana } \\
(3.34 \%)\end{array}$ & $\begin{array}{l}\text { Burseraceae } \\
(9.71 \%)\end{array}$ & $\begin{array}{l}\text { Liana forest/Lasiacis thicket, } \\
\text { with Oenocarpus spp. } \\
\text { nearby }\end{array}$ & Present & Present & Yes & Steep slope & $650-800$ & $\begin{array}{l}\text { Very dark } \\
\text { brown - dark } \\
\text { reddish } \\
\text { brown }\end{array}$ \\
\hline
\end{tabular}




\begin{tabular}{|c|c|c|c|c|c|c|c|c|c|c|c|c|c|c|}
\hline 8 & $\begin{array}{l}4.01726 ; \\
-52.40909\end{array}$ & LTN3 & 100 & 39 & 589 & $\begin{array}{l}\text { Oenocarpus } \\
\text { bataua }(7.47 \%)\end{array}$ & \begin{tabular}{|l} 
Meliaceae \\
$(12.9 \%)$
\end{tabular} & $\begin{array}{l}\text { Middle-high to high canopy } \\
\text { forest with Oenocarpus } \\
\text { bataua }\end{array}$ & $\begin{array}{l}\text { Present, } \\
\text { intact urn- } \\
\text { like ceramics }\end{array}$ & Present & Yes & $\begin{array}{l}\text { Hilltop of the } \\
\text { ring-ditched } \\
\text { hill }\end{array}$ & $700-720$ & $\begin{array}{l}\text { Dark brown } \\
- \text { red }\end{array}$ \\
\hline 9 & $\begin{array}{l}4.07942 ; \\
-52.67168\end{array}$ & -- & -- & -- & -- & -- & -- & $\begin{array}{l}\text { Liana forest with a low and } \\
\text { discontinuous canopy }\end{array}$ & Present & Present & Yes & $\begin{array}{l}\text { Circular } \\
\text { ditch on a } \\
\text { plateau }\end{array}$ & $850-940$ & $\begin{array}{l}\text { Brown - } \\
\text { yellowish } \\
\text { brown }\end{array}$ \\
\hline 10 & $\begin{array}{l}4.08133 \\
-52.6731\end{array}$ & LTN4 & 111 & 40 & 493 & $\begin{array}{l}\text { Qualea rosea } \\
(8.52 \%)\end{array}$ & $\begin{array}{l}\text { Leguminosae } \\
(13.18 \%)\end{array}$ & Middle-high canopy forest & Unobserved & Present & No & Plateau & $890-930$ & \begin{tabular}{|l} 
Dark \\
yellowish \\
brown - \\
brownish \\
yellow
\end{tabular} \\
\hline 11 & $\begin{array}{l}4.07898 ; \\
-52.67417\end{array}$ & LTN6 & 116 & 40 & 461 & $\begin{array}{l}\text { Oenocarpus } \\
\text { bataua }(5.21 \%)\end{array}$ & $\begin{array}{l}\text { Leguminosae } \\
(13.45 \%)\end{array}$ & $\begin{array}{l}\text { High canopy forest, sparse } \\
\text { understory, Oenocarpus } \\
\text { bacaba, O. bataua }\end{array}$ & Present (few) & Present & Yes & Plateau & $850-920$ & \begin{tabular}{|l} 
Dark \\
yellowish \\
brown - \\
brownish \\
yellow
\end{tabular} \\
\hline 12 & $\begin{array}{l}.08347 ; \\
-52.67375\end{array}$ & \begin{tabular}{|l|} 
LTN5 \\
\end{tabular} & 101 & 37 & 499 & $\begin{array}{l}\text { Qualea rosea } \\
(4.81 \%)\end{array}$ & \begin{tabular}{|l} 
Lecythidaceae \\
$(12.83 \%)$
\end{tabular} & \begin{tabular}{|l|} 
High canopy forest with \\
Astrocaryum sciophilum
\end{tabular} & Unobserved & Present & No & Plateau & $810-850$ & $\begin{array}{l}\text { Dark } \\
\text { yellowish } \\
\text { brown- } \\
\text { brownish } \\
\text { yellow }\end{array}$ \\
\hline
\end{tabular}


Table 2 Number of soil samples searched for charcoals in the 12 study sites, using three complementary methods, along with the total number of analyzed charcoal fragments and the number of identifiable taxa. For sites 1 to 8 , searching for charcoals in soil excavated during the digging of the pit is considered to be similar to searching an uprooted-tree mound because vertical distribution is lost

\begin{tabular}{|c|c|c|c|c|c|}
\hline Site & $\begin{array}{l}\text { No. of pit profile } \\
\text { samples } \\
\text { (each } 10-\mathrm{cm} \text { depth) }\end{array}$ & $\begin{array}{l}\text { No. of auger cores } \\
(\max . \text { depth in } \mathrm{cm})\end{array}$ & $\begin{array}{l}\text { No. of tree } \\
\text { uprooting mounds/ } \\
\text { excavated pit soil }\end{array}$ & $\begin{array}{l}\text { Total no. of } \\
\text { charcoal } \\
\text { fragments }\end{array}$ & $\begin{array}{l}\text { No. of } \\
\text { identifiable } \\
\text { taxa }\end{array}$ \\
\hline 1 & 6 & $20(80)$ & $0 / 1$ & 290 & 39 \\
\hline 2 & 3 & $26(90)$ & $0 / 1$ & 652 & 26 \\
\hline 3 & 6 & $16(130)$ & $0 / 1$ & 350 & 30 \\
\hline 4 & 5 & - & $0 / 1$ & - & - \\
\hline 5 & 4 & - & $0 / 1$ & - & - \\
\hline 6 & 5 & $23(60)$ & $0 / 1$ & 93 & 11 \\
\hline 7 & 5 & - & $0 / 1$ & 6 & 5 \\
\hline 8 & 4 & $6(80)$ & $0 / 1$ & 47 & 9 \\
\hline 9 & 7 & $17(60)$ & $9 / 1$ & 253 & 43 \\
\hline 10 & - & $16(60)$ & $11 / 0$ & 113 & 18 \\
\hline 11 & - & - & $15 / 0$ & 60 & 15 \\
\hline 12 & - & - & $3 / 0$ & 52 & 3 \\
\hline
\end{tabular}

